\title{
POTENSI PENERAPAN SISTEM ELECTRONIC ROAD PRICING (ERP) DI DKI JAKARTA
}

\author{
Firya Adilah", Achmad Nadjam² \\ 1,2 Jurusan Teknik Sipil Politeknik Negeri Jakarta Kampus UI Depok 16424. \\ e-mail :firyaaadilah@gmail.com, achmad.nadjam@yahoo.com
}

\begin{abstract}
The increasing needs of community travel in DKI Jakarta area that is not balanced with the growth of roads have resulted in traffic congestion. One effort to address the problem is to implement a traffic restriction policy using Electronic Road Pricing system (ERP). This research aims to analyze the existing condition of traffic characteristics on the road sections reviewed, analyze the opportunities of road users mobility against ERP system, and analyze the potential implementation of ERP system. Data collected from traffic survey results and distribution of questionnaires to users of four-wheeled vehicles. To analyze the existing condition of traffic characteristics using the calculation method of Pedoman Kapasitas Jalan Indonesia 2014, and to analyze the chances of road users to ERP system using binary Logistic regression analysis method. Meanwhile, to analyze the potential implementation of ERP system is to compare the cost of congestion before ERP with predictions when ERP policy is implemented. From the results of the calculations and analysis, the road condition will experience a decrease in vehicle volume by 50\% when ERP system is applied so that the degree of saturation in the road is very good compared to the condition before implementation of ERP system. Besides, there are congestion cost savings of Rp.532,291.998/hour for rush hour and Rp.294,167.785/hour for peak hours when ERP system is implemented. Therefore, the result is that the ERP system has good potential to be applied to reduce congestion in DKI Jakarta.
\end{abstract}

Keywords : Congestion Cost, Traffic, Electronic Road Pricing (ERP), Displacement Opportunities

\begin{abstract}
ABSTRAK
Peningkatan kebutuhan perjalanan masyarakat di wilayah DKI Jakarta yang tidak seimbang dengan pertumbuhan jalan menyebabkan kemacetan. Salah satu upaya untuk menangani permasalahan tersebut yaitu dengan menerapkan kebijakan pembatasan lalu lintas menggunakan Sistem Jalan Berbayar Elektronik atau Electronic Road Pricing (ERP). Penelitian ini bertujuan untuk menganalisis kondisi eksisting karakteristik lalu lintas pada ruas jalan yang ditinjau, menganalisis peluang perpindahan pengguna jalan terhadap sistem ERP, dan menganalisis potensi penerapan sistem ERP. Data yang dikumpulkan dari hasil survey lalu lintas dan penyebaran kuesioner kepada pengguna kendaraan roda empat. Untuk menganalisis kondisi eksisting karakteristik lalu lintas menggunakan metode perhitungan Pedoman Kapasitas Jalan Indonesia 2014. Dan untuk mengetahui peluang perpindahan pengguna jalan terhadap sistem ERP menggunakan metode analisis regresi logistik biner. Sedangkan, untuk mengetahui potensi penerapan sistem ERP yaitu dengan membandingkan biaya kemacetan sebelum ERP dengan prediksi ketika kebijakan ERP diberlakukan. Dari hasil perhitungan dan analisis, kondisi jalan akan mengalami penurunan volume kendaraan sebesar $50 \%$ apabila sistem ERP diterapkan sehingga derajat kejenuhan di jalan tersebut menjadi sangat baik dibandingkan dengan sebelum kebijakan sistem ERP. Selain itu, terjadi penghematan biaya kemacetan sebesar Rp532,291.998/jam untuk jam sibuk pagi dan Rp. 294,167.785/jam untuk jam sibuk sore apabila sistem ERP diberlakukan. Sehingga didapatkan hasil bahwa sistem ERP memiliki potensi yang baik untuk diterapkan guna mengurangi kemacetan yang ada di DKI Jakarta.
\end{abstract}

Kata kunci : Biaya Kemacetan, Lalu Lintas, Jalan Berbayar Elektronik, Peluang Perpindahan

PENDAHULUAN

Kebutuhan perjalanan penduduk DKI Jakarta dan wilayah sekitarnya untuk melakukan aktivitas sangat tinggi.
Namun, kebutuhan tersebut tidak diimbangi dengan pertumbuhan jalannya, sehingga menyebabkan terjadinya kemacetan dibeberapa ruas jalan. Pemerintah Provinsi DKI Jakarta 
sudah melakukan berbagai macam cara untuk menangani kemacetan ini salah satunya dengan menerapkan pembatasan lalu lintas kendaraan bermotor. Sebelumnya metode yang digunakan untuk melakukan pembatasan lalu lintas yaitu sistem three in one dan sistem ganjil-genap. Namun, kedua sistem tersebut dinilai tidak efektif untuk diterapkan. Sehingga dicanangkan sistem Jalan Berbayar Elektronik atau Electronic Road Pricing (ERP).

Sistem ERP adalah suatu kebijakan pemberlakuan jalan berbayar pada suatu ruas jalan untuk setiap kendaraan yang melewatinya. Sistem ini memiliki tujuan untuk mengurangi kemacetan dengan mengenakan biaya kepada pengguna mobil pribadi pada jam-jam sibuk. Sehingga, pengguna mobil harus memutuskan akan tetap melewati area tersebut atau memilih untuk berpindah ke moda transportasi umum atau jalan alternatif lainnya [1].

Tujuan dari penelitian ini yaitu untuk melakukan peninjauan apakah sistem ERP ini memiliki potensi yang baik untuk diterapkan di DKI Jakarta berdasarkan derajat kejenuhan dan biaya kemacetan yang terjadi.

\section{Penelitian Terdahulu}

Penelitian mengenai penerapan ERP telah banyak dilakukan oleh penelitipeneliti sebelumnya. Sehingga penelitian ini mengacu pada penelitian terdahulu mengenai potensi dan kesiapan dalam penerapan ERP apabila dilihat dari kinerja ruas jalan dan persepsi pengguna jalan terhadap kebijakan ERP [2].

Penelitian lainnya yaitu mengenai pembebanan lalu lintas dengan ERP serta sensitivitas tarif ERP untuk mengetahui pengaruhnya terhadap penerapan ERP [3].

Penelitian mengenai kelayakan penerapan ERP berdasarkan presentase perpindahan pengguna jalan, kondisi jalan sebelum dan sesudah penerapan ERP, serta kelayakan dari aspek ekonomi dengan meninjau biaya operasional kendaraan (BOK) [4].

\section{Penerapan Electronic Road Pricing (ERP)}

Akibat kapasitas jalan yang tidak memadai, kerugian akibat kemacetan yang terjadi sangat besar, dan tren penggunaan kendaraan bermotor yang membuat tingginya jumlah kendaraan menjadikan alasan mengapa perlu diterapkannya sistem ERP ini [5]. Penerapan sistem ERP dengan mengenakan tarif tertentu bagi pengguna mobil pribadi. Tarif yang akan dikenakan adalah tarif puncak dan tarif normal yang disesuaikan dengan tingkat kepadatan lalu lintas dan kecepatan kendaraan dalam area ERP [6].

\section{Karakteristik Lalu Lintas}

Berdasarkan Pedoman Kapasitas Jalan Indonesia 2014 [7], untuk meninjau karakteristik lalu lintas didalamnya terdapat komponen, kecepatan arus bebas, kapasitas jalan, derajat kejenuhan, dan tingkat pelayanan jalan.

Untuk menentukan kecepatan arus bebas, dapat menggunakan persamaan dibawah ini:

$$
V_{B}=\left(V_{B D}+V_{B L}\right) \times F V_{B H S} \times F V_{B U K}
$$

Dimana:

$$
\begin{aligned}
\mathrm{V}_{\mathrm{B}}= & \text { adalah kecepatan arus bebas } \\
& \text { untuk Kendaraan Ringan }(\mathrm{KR}) \\
& \text { pada kondisi lapangan } \\
& (\mathrm{km} / \text { jam }) \\
\mathrm{V}_{\mathrm{BD}}= & \text { adalah kecepatan arus bebas } \\
& \text { dasar untuk Kendaraan Ringan } \\
& (\mathrm{KR}) \\
\mathrm{V}_{\mathrm{BL}}= & \text { adalah nilai penyesuaian } \\
& \begin{array}{l}
\text { kecepatan akibat lebar jalan } \\
\\
(\mathrm{km} / \text { jam) }
\end{array} \\
\mathrm{FV}_{\mathrm{BHS}}= & \text { adalah faktor penyesuaian } \\
& \text { kecepatan bebas akibat } \\
& \text { hambatan samping }
\end{aligned}
$$



$\mathrm{FV}_{\mathrm{BUK}}=$ adalah faktor penyesuaian kecepatan bebas untuk ukuran kota

Nilai kapasitas jalan dapat dihitung menggunakan persamaan berikut:

$C=C_{0} x F C_{L J} x F C_{P A} x F C_{H S} x F C_{U K}$

Dimana:

$\mathrm{C}=$ Kapasitas (smp/jam).

$\mathrm{C} 0=$ Kapasitas dasar (smp/jam).

$\mathrm{FC}_{\mathrm{LJ}}=$ Faktor penyesuaian lebar jalan.

$\mathrm{FC}_{\mathrm{PA}}=$ Faktor penyesuaian pemisah arah.

$\mathrm{FC}_{\mathrm{HS}}=$ Faktor penyesuaian hambatan samping dan bahu jalan.
$\mathrm{FC}_{\mathrm{UK}}=$ Faktor penyesuaian ukuran kota.

Sedangkan untuk menentukan nilai derajat kejenuhan suatu ruas jalan dapat menggunakan persamaan dibawah ini:

$D_{J}=\frac{Q}{C}$

Dimana:

DJ = Derajat kejenuhan

$\mathrm{Q}=$ Arus lalu lintas ( $\mathrm{smp} / \mathrm{jam})$

$\mathrm{C}=$ Kapasitas (smp/jam)

Menurut Peraturan Menteri Pehubungan Keputusan Menteri (KM) 14 Tahun 2006, tingkat pelayanan jalan diklasifikasikan seperti tabel 1 berikut.

Tabel 1. Tingkat Pelayanan Jalan

\begin{tabular}{|c|c|}
\hline $\begin{array}{c}\text { Tingkat } \\
\text { Pelayanan }\end{array}$ & Karakteristik Operasi Terkait \\
\hline $\mathrm{A}$ & $\begin{array}{l}\text { 1. Arus bebas } \\
\text { 2. Kecepatan perjalanan rata-rata }>80 \mathrm{Km} / \mathrm{jam} \\
\text { 3. V/C ratio }<0,6 \\
\text { 4. Load factor pada simpang }=0\end{array}$ \\
\hline B & $\begin{array}{l}\text { 1. Arus stabil } \\
\text { 2. Kecepatan perjalanan rata-rata turun } \mathrm{s} / \mathrm{d}>40 \mathrm{Km} / \mathrm{jam} \\
\text { 3. V/C ratio }<0,7 \\
\text { 4. Load factor }<0,1\end{array}$ \\
\hline $\mathrm{C}$ & $\begin{array}{l}\text { 1. Arus stabil } \\
\text { 2. Kecepatan perjalanan rata-rata turun } \mathrm{s} / \mathrm{d}>30 \mathrm{Km} / \mathrm{jam} \\
\text { 3. V/C ratio }<0,8 \\
\text { 4. } \text { Load factor }<0,3\end{array}$ \\
\hline $\mathrm{D}$ & $\begin{array}{l}\text { 1. Mendekati arus tidak stabil } \\
\text { 2. Kecepatan perjalanan rata-rata turun } \mathrm{s} / \mathrm{d}>25 \mathrm{Km} / \mathrm{jam} \\
\text { 3. V/C ratio }<0,9 \\
\text { 4. Load factor }<0,7\end{array}$ \\
\hline $\mathrm{E}$ & $\begin{array}{l}\text { 1. Arus tidak stabil, terhambat, dengan tundaan yang tidak dapat } \\
\text { ditolerir } \\
\text { 2. Kecepatan perjalanan rata-rata sekitar } 25 \mathrm{Km} / \mathrm{jam} \\
\text { 3. Volume pada kapasitas } \\
\text { 4. Load factor pada simpang }<1\end{array}$ \\
\hline $\mathrm{F}$ & $\begin{array}{l}\text { 1. Arus tertahan, macet } \\
\text { 2. Kecepatan perjalanan rata-rata }<15 \mathrm{Km} / \mathrm{jam} \\
\text { 3. V/C ratio permintaan melebihi } 1\end{array}$ \\
\hline
\end{tabular}

\section{Peluang Perpindahan Pengguna}

Jalan

$\begin{array}{lrr}\text { Untuk menentukan } & \text { peluang } \\ \text { perpindahan } & \text { pengguna } & \text { jalan }\end{array}$

menggunakan regresi logistik biner.

Menurut Hayati pada tahun 2002 [8],

Regresi logistik biner adalah suatu analisis untuk melihat pengaruh variabel bebas terhadap variabel terikatnya, dimana variabel terikatnya memiliki dua nilai, misalnya "bersedia" dan "tidak bersedia". Model umum regresi logistik yaitu :

$\pi(x)=\frac{\exp ^{\left(\beta_{0}+\beta_{1} x\right)}}{1+\exp ^{\left(\beta_{0}+\beta_{1} x\right)}}$

Dimana 
$\pi(\mathrm{x})=$ peluang perpindahan

$\beta 0=$ konstanta regresi

$\beta 1=$ konstanta regresi variabel bebas

$\chi \quad=$ variabel bebas

Model umum regresi logistik tersebut merupakan fungsi non linear, sehingga untuk mengetahui adanya hubungan antara variabel bebas dan variabel terikatnya, fungsi non linear tersebut dibuat menjadi fungsi tersebut linear maka harus dilakukan transformasi logit menjadi,

$\operatorname{logit}[\pi(x)]=\beta_{0}+\beta_{1} x$

\section{Biaya Operasional Kendaraan}

Berdasarkan SNI Pd-T-15-2005-B [9], Biaya operasional kendaraan terdiri dari biaya tetap dan biaya tidak tetap.

$\mathrm{BOK}=\mathrm{BT}+\mathrm{BTT}$.

Dimana :

BOK = Biaya Operasional Kendaraan BT = Biaya tetap yang terdiri dari biaya penyusutan dan biaya overhead BTT = Biaya tidak tetap yang terdiri dari biaya konsumsi bahan bakar (BiBBMj), biaya konsumsi oli (BOi), biaya konsumsi suku cadang (BPi), biaya upah tenaga pemelihara (BUi), dan biaya konsumsi ban (BBi).

\section{Nilai Waktu Perjalanan}

Untuk menghitung nilai waktu menggunakan metode pendapatan, dengan persamaan (7) [10].

$\lambda=\mathrm{PDRB} /($ Orang Waktu Kerja tahunan/orang)

Dimana :

$\lambda=$ Nilai Waktu (Rupiah/kendaraan/ jam)

$\mathrm{PDRB}=$ Pendapatan Domestik Regional Bruto

\section{Biaya Kemacetan}

Menurut Imam Basuki dan Siwadi pada tahun 2008 [11], Biaya kemacetan merupakan biaya perjalanan yang diakibatkan adanya tundaan lalu lintas serta penambahan valume kendaraan yang mendekati atau melebihi kapasitas jalan. Untuk menghitung biaya kemacetan berdasarkan model kaitan antara keceparan dengan biaya kemacetan dapat menggunakan persamaan berikut

$C=N \times\left\{G A+\left(1-\frac{A}{B}\right) \times V^{\prime}\right\} \times T(8)$

Dimana :

$\mathrm{C}$ = Biaya kemacetan (Rupiah)

$\mathrm{N}$ = Jumlah kendaraan (kendaraan)

$\mathrm{G}=$ Biaya Operasional Kendaraan (Rp/Kend/jam)

$\mathrm{A}=$ Kendaraan dengan kecepatan eksisiting $(\mathrm{km} / \mathrm{jam})$

$\mathrm{B}=$ Kendaraan dengan kecepatan ideal $(\mathrm{km} / \mathrm{jam})$

$\mathrm{V}^{\prime}$ = Nilai waktu perjalanan kendaraan cepat (Rp/Kend/jam)

$\mathrm{T}=$ Jumlah Waktu Antrian (Jam)

\section{METODE PENELITIAN}

\section{Metode Pengumpulan Data}

Pengumpulan data primer dilakukan dengan melakukan survey lalu lintas Jalan Medan Merdeka Barat pada hari kerja jam sibuk pagi dan sore hari yang menghasilkan data geometrik jalan, volume kendaraan, kecepatan kendaraan pada jarak tempuh 100 meter, serta hambatan samping yang terjadi pada radius pengamatan 200 meter. Dan diperlukan data melalui penyebaran kuesioner dengan responden sesuai jumlah sampel yang telah ditentukan. Bentuk pertanyaan yang ditujukan untuk mengetahui besarnya peluang terjadinya perpindahan pengguna kendaraan terhadap kebijakan ERP pada ruas jalan yang diamati. Selain itu, dilakukan survei mengenai harga BBM, harga kendaraan baru, harga ban kendaraan, dan harga pelumas kendaraan serta upah tenaga pemelihara dan kekasaran jalan yang digunakan untuk perhitungan biaya akibat adanya kemacetan.

Data sekunder yang digunakan yaitu data tarif ERP untuk koridor Blok M 
hingga Kota, data jumlah penduduk Kota Jakarta Pusat Tahun 2019 dan Pendapatan Domestik Regional Bruto (PDRB) tahun 2019.

\section{Metode Analisis Data}

Terdapat tiga analisis yang dilakukan dalam penelitian ini yaitu, analisis mengenai kondisi karakteristik lalu lintas jalan yang akan diterapkan ERP. Perhitungan analisis ini berdasarkan PKJI 2014. Selanjutnya, dilakukan analisis peluang perpindahan pengguna jalan terhadap penerapan ERP dengan menggunakan analisis regresi logistik biner. Variabel bebas dalam analisis ini

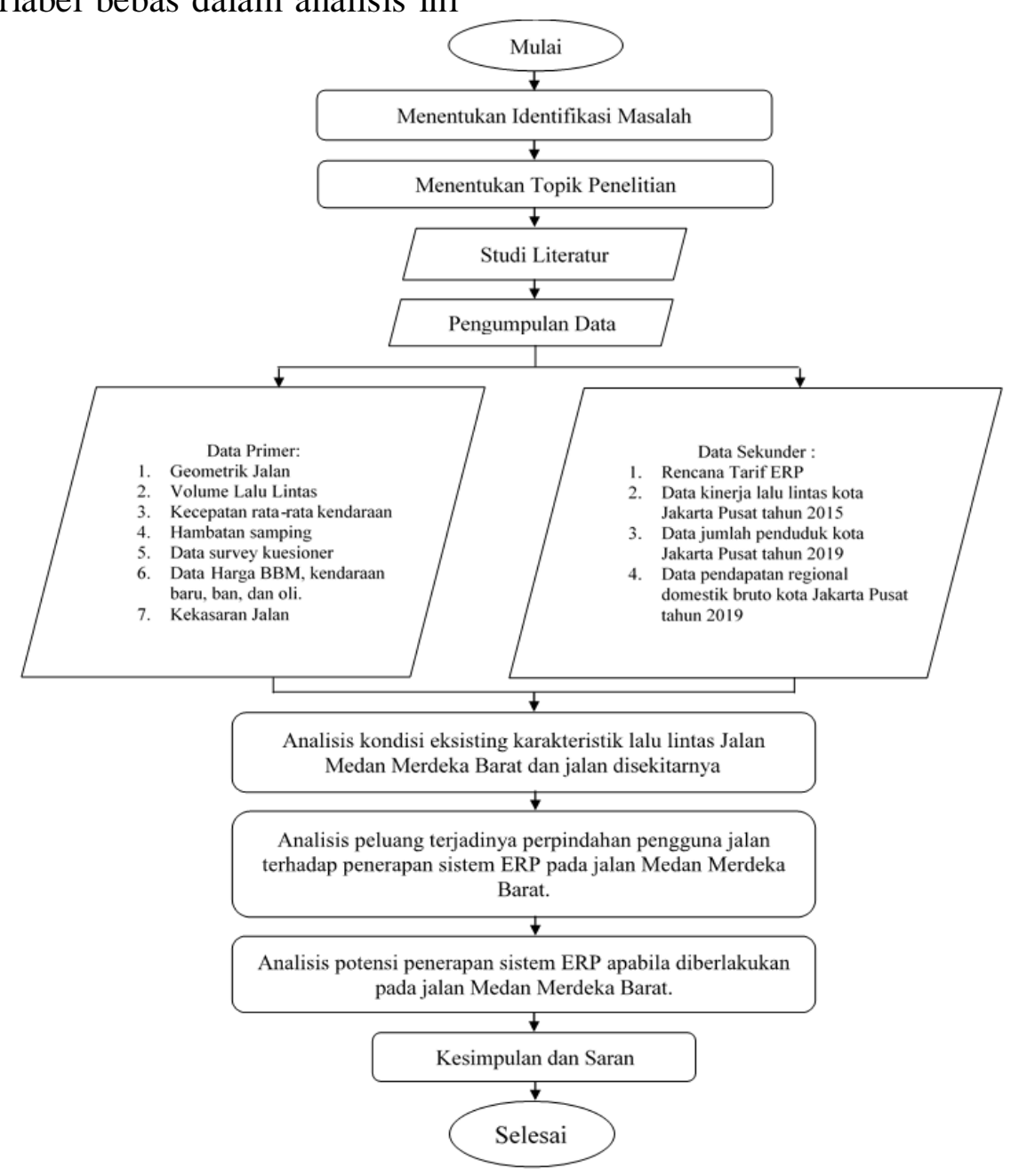

Gambar 1. Bagan Alir Penelitian

\section{HASIL dan PEMBAHASAN}

Analisis karakeristik lalu lintas dihitung berdasarkan PKJI 2014 dan didapatkan volume lalu lintas total pada hari kerja yaitu tarif ERP dan Frekuensi Perjalan, sedangkan variabel terikatnya yaitu kesediaanya untuk tetap melewati area ERP dan ketidaksediaannya untuk melewati area ERP. Kemudian dilakukan analisis potensi adanya penghematan akibat biaya kemacetan yang terjadi ketika sistem ERP diberlakukan. Dari ketiga analisis tersebut maka disimpulkan apakah wilayah tersebut berpotensi untuk diterapkan sistem ERP atau tidak. Bagan alir mengenai metode penelitian dapat dilihat pada gambar 1 . 
pada kelas rendah. Berdasarkan persamaan (1) didapatkan nilai kecepatan arus bebas untuk jam sibuk pagi sebesar $58.41 \mathrm{~km} / \mathrm{jam}$ dan untuk jam sibuk sore yaitu $59 \mathrm{~km} / \mathrm{jam}$. Nilai kapasitas jalan Medan Merdeka Barat yang dihitung berdasarkan persamaan (2) yaitu sebesar $4656.96 \mathrm{skr} / \mathrm{jam}$ untuk jam sibuk pagi. Sedangkan jam sibuk sore sebear 4752 skr/jam. Sehingga dapat ditentukan nilai derajat kejenuhan pada jam sibuk pagi dan sore berdasarkan persamaan (3) yaitu sebesar 0.89 dan 0.88. Oleh karena itu, apabila dilihat dari tingkat pelayanan jalannya berdasarkan klasifikasi pada tabel 1, maka Jalan Medan Merdeka Barat memiliki tingkat pelayanan D dimana menunjukan bahwa arus kendaraan mendekati tidak stabil dengan kecepatan perjalanan rata-ratanya $>25 \mathrm{~km} / \mathrm{jam}$ serta derajat kejenuhan dibawah 0.9 .

Tabel 2. Tingkat Pelayanan Jalan Medan Merdeka Barat

\begin{tabular}{|c|c|c|c|c|c|c|}
\hline Waktu & $\begin{array}{l}\text { olume } \\
\text { sr/jam) }\end{array}$ & $\begin{array}{c}\text { Kapasitas } \\
\text { Dasar } \\
\text { (C0) }\end{array}$ & $\begin{array}{c}\text { Kapasitas } \\
\text { Aktual }\end{array}$ & $\begin{array}{l}\text { Kecep } \\
\text { Kenda } \\
\text { Eksist } \\
(\mathbf{k m} / \mathbf{j}\end{array}$ & DJ & LOS \\
\hline $\begin{array}{l}\text { Jam } \\
\text { Pagi }\end{array}$ & 4164 & 4950 & & 27.94 & 0.89 & D \\
\hline $\begin{array}{l}\text { n Sibuk } \\
\text { re }\end{array}$ & 4194 & 4950 & 4752.00 & 25.99 & 0.88 & D \\
\hline \multicolumn{4}{|c|}{$\begin{array}{l}\text { Analisis Peluang Perpindahan } \\
\text { Pengguna Jalan Terhadap Penerapan } \\
\text { ERP } \\
\text { Berdasarkan hasil penelitian frekuensi } \\
\text { perjalanan pengguna jalan setiap hari, } \\
\text { atau >4 kali seminggu sebesar } 67,9 \% \text {, } \\
\text { untuk frekuensi perjalanan } 2-3 \text { kali } \\
\text { seminggu sebesar } 12,3 \% \text {, untu frekuensi } \\
\text { perjalanan } 1 \text { kali seminggu sebesar } \\
7,5 \% \text { dan untuk frekuensi perjalanan } 2- \\
4 \text { kali sebulan sebesar } 12,3 \% \text {. }\end{array}$} & \multicolumn{3}{|c|}{$\begin{array}{l}\text { Sebanyak } 25 \text { responden bersedia untuk } \\
\text { membayar Rp. } 40,000-\text { Rp. } 50,000 \text {, } \\
\text { adapun } 22 \text { responden bersedia untuk } \\
\text { membayar Rp. } 20,000-\text { Rp. } 30,000 \text {, } \\
\text { sedangkan } 20 \text { responden lainnya } \\
\text { bersedia untuk membayar Rp. 5,000- } \\
\text { Rp. } 15,000 \text {. }\end{array}$} \\
\hline \multicolumn{4}{|c|}{$\begin{array}{l}\text { Sebanyak } 67 \text { responden setuju unt } \\
\text { melewati ruas jalan Medan Merdel } \\
\text { Barat apabila sistem ERP berlak } \\
\text { sedangkan } 39 \text { responden lainnya tid }\end{array}$} & \multicolumn{3}{|c|}{$\begin{array}{l}\text { Peluang terjadinya perpindahan } \\
\text { didapatkan dari hasil analisis dengan } \\
\text { menggunakan program SPSS sebagai } \\
\text { berikut: }\end{array}$} \\
\hline
\end{tabular}

Tabel 3. Analisis Regresi Logistik Biner dengan menggunakan SPSS

\begin{tabular}{lrrrrrr}
\multicolumn{1}{c}{$\mathbf{X}$} & \multicolumn{1}{c}{$\mathbf{B}$} & S.E. & Wald & df & Sig. & $\operatorname{Exp(B)}$ \\
\hline $\begin{array}{l}\text { Tarif } \\
50000\end{array}$ & 19.075 & 7891.067 & 0.000 & 1 & 0.998 & 1.925 \\
Tarif & -1.400 & 17595.963 & 0.000 & 1 & 1.000 & 0.247 \\
40000 & & & & & & \\
Tarif & 0.023 & 18975.047 & 0.000 & 1 & 1.000 & 1.023 \\
30000 & & & & & & \\
Tarif & 22.143 & 9934.110 & 0.000 & 1 & 0.998 & 4.137 \\
20000 & & & & & & \\
Frekuensi & 0.357 & 0.171 & 4.353 & 1 & 0.037 & 0.700 \\
Constant & -0.656 & 0.682 & 0.925 & 1 & 0.336 & 1.927 \\
\hline
\end{tabular}


Berdasarkan tabel 3, variabel frekuensi perjalanan merupakan variabel bebas yang berpengaruh terhadap variabel terikatnya karena nilai signifikannya kurang dari nilai signifikansi yang telah ditetapkan yaitu 0.05. Maka didapatkan fungsi logitnya berdasarkan persamaan (5) untuk mencari nilai peluang perpindahan.

Setelah itu, fungsi logit dimasukkan ke dalam persamaan (4).

Apabila ditentukan frekuensi perjalanan yang digunakan (x) adalah 5 kali seminggu, maka dengan persamaan (4) didapat nilai fungsi peluang yaitu 0.76 . Untuk mendapatkan presentase pengguna jalan yang tetap akan melewati area ERP berdasarkan frekuensi perjalanan 5 kali seminggu, dapat dihitung dengan cara membagi jumlah responden yang bersedia lewat dengan total responden kemudian dikalikan dengan nilai peluang maka didapatkan presentase pengguna jalan yang bersedia melewati area ERP adalah 50\%. Sehingga terdapat 50\% responden akan memilih moda transportasi lain atau mencari rute alternatif lainnya.

\section{Analisis Potensi Penghematan Biaya Akibat Kemacetan}

Untuk menganalisis potensi penghematan biaya akibat kemacetan diperhitungkan terlebih dahulu biaya kemacetan pada kondisi eksisting kemudian diperhitungkan prediksi biaya kemacetan pada saat ERP diberlakukan. Untuk menghitung biaya kemacetan terdapat komponen biaya operasional kendaraan dan nilai waktu. Sehingga terlebih dahulu memperhitungkan kedua komponen tersebut.

\section{Biaya Operasional Kendaraan}

Berdasarkan tabel 4 besarnya total biaya tetap yaitu Rp.39.863.705/km dan besar total biaya tidak tetap yaitu Rp.38.678.424/km dapat dilihat pada tabel 5. Sehingga dengan menggunakan persamaan (6) besarnya total biaya operasional kendaraan yaitu $\mathrm{Rp}, 78.542,130 / \mathrm{km}$.

Tabel 4. Biaya Tetap

\begin{tabular}{lccc}
\hline \multirow{2}{*}{ Jenis Kendaraan } & Depresiasi (D) & Biaya Overhead & $\begin{array}{c}\text { Biaya } \\
\text { Tetap }\end{array}$ \\
\cline { 2 - 4 } & $\mathrm{Rp} / \mathrm{km}$ & $\mathrm{Rp} / \mathrm{km}$ & $\mathrm{Rp} / \mathrm{km}$ \\
\hline Sedan & 4660.000 & 1688.784 & 6348.784 \\
Utiliti & 3236.800 & 1385.749 & 4622.549 \\
Bus Kecil & 1787.200 & 2029.726 & 3816.926 \\
Truk Ringan & 1845.600 & 1815.945 & 3661.545 \\
Bus Besar & 7120.000 & 2783.573 & 9903.573 \\
Truk Sedang & 2144.000 & 2074.303 & 4218.303 \\
Truk Berat & 4644.000 & 2648.024 & 7292.024 \\
\hline
\end{tabular}

Tabel 5. Biaya Tidak Tetap

\begin{tabular}{lrrrrrr}
\hline \multicolumn{1}{c}{ Jenis } & \multicolumn{1}{c}{ BiBBMj } & \multicolumn{1}{c}{ BOi } & \multicolumn{1}{c}{ BPi } & \multicolumn{1}{c}{ BUi } & \multicolumn{1}{c}{ BBi } & \multicolumn{1}{c}{ BTT } \\
\cline { 2 - 7 } Kendaraan & Rupiah/km & Rupiah/km & Rupiah/km & Rupiah/km & Rupiah/km & \multicolumn{1}{c}{ Rupiah/km } \\
\hline Sedan & 766.415 & 122.519 & 259.111 & 1648.376 & 49.286 & 2845.706 \\
Utiliti & 895.138 & 131.275 & 179.976 & 1648.376 & 67.320 & 2922.085 \\
Bus Kecil & 1400.326 & 120.015 & 200.157 & 5207.875 & 305.432 & 7233.805 \\
Truk & & & & & & \\
Ringan & 2522.976 & 120.027 & 72.781 & 3029.621 & 479.863 & 6225.268 \\
\hline
\end{tabular}


Firya Adilah dan Achmad Nadjam, Analisis Rencana Penerapan...

\begin{tabular}{lrrrrrr}
\hline \multicolumn{1}{c}{ Jenis } & \multicolumn{1}{c}{ BiBBMj } & \multicolumn{1}{c}{ BOi } & \multicolumn{1}{c}{ BPi } & \multicolumn{1}{c}{ BUi } & \multicolumn{1}{c}{ BBi } & \multicolumn{1}{c}{ BTT } \\
\cline { 2 - 6 } Kendaraan & Rupiah/km & Rupiah/km & Rupiah/km & Rupiah/km & Rupiah/km & Rupiah/km \\
\cline { 2 - 6 } Bus Besar & 1182.496 & 240.020 & 251.564 & 3478.353 & 99.005 & 5251.437 \\
$\begin{array}{l}\text { Truk } \\
\text { Sedang }\end{array}$ & 2053.342 & 240.033 & 175.860 & 4434.342 & 171.549 & 7075.126 \\
$\begin{array}{l}\text { Truk } \\
\text { Berat }\end{array}$ & 2950.656 & 480.050 & 68.082 & 2257.952 & 1368.256 & 7124.996 \\
\hline
\end{tabular}

\section{Nilai Waktu Perjalanan}

Berdasarkan perhitungan pada persamaan (7) nilai waktu perjalanan sebesar 0.04379 rupiah/jam.

\section{Biaya Kemacetan}

Berdasarkan perhitungan pada persamaan (8), maka didapatkan besar biaya kemacetan kondisi eksisiting pada Jalan Medan Merdeka Barat yaitu Rp,1,462,825.549/jam untuk jam sibuk pagi dan Rp. 1,164,915.791/jam untuk jam sibuk sore. Apabila sistem ERP beroperasi pada Jalan Medan Merdeka Barat, maka volume kendaraan mengalami pengurangan sebesar $50 \%$. Sehingga biaya kemacetannya mengalami pengurangan juga. Besarnya biaya kemacetan pada saat ERP diberlakukan yaitu Rp.766,647.747/jam untuk jam sibuk pagi dan Rp.758,682.075/jam untuk jam sibuk sore dapat dilihat pada gambar 2 .

Sehingga dapat disimpulkan bahwa terjadi pengurangan biaya kemacetan pada saat sistem ERP beroperasi. Pada jam sibuk pagi, terjadi penghematan biaya kemacetan sebesar Rp.532,291.998./jam. Sedangkan jam sibuk sore, penghematan biaya kemacetan sebesar Rp.294,167.785/jam. Sehingga penerapan sistem ERP memiliki potensi untuk mengurangi tingkat kemacetan yang berhubungan dengan kerugian materiil.

\section{KESIMPULAN}

Berdasarkan hasil analisis rencana penerapan Electronic Road Pricing pada Jalan Medan Merdeka Barat dapat disimpulkan bahwa kondisi karakteristik lalu lintas jalan tersebut memiliki nilai derajat kejenuhan terbesarnya yaitu 0.89 . Hal tersebut menandakan bahwa arus lalu lintas pada Jalan Medan Merdeka Barat mendekati tidak stabil dengan kecepatan kendaraan turun menjadi $>25 \mathrm{~km} / \mathrm{jam}$. Dalam analisis peluang terjadinya perpindahan pengguna jalan terhadap diberlakukannya sistem ERP dengan menggunakan analisis regresi logistik biner didapatkan sebesar 50\% dari responden dengan rata-rata frekuensi perjalanan 5 kali seminggu bersedia untuk tetap melewati area ERP. Sedangkan 50\% lainnya memilih untuk tidak melewati ERP dan beralih ke moda transportasi umum ataupun mengganti rute perjalanannya melewati rute lain. Kemudian apabila dilihat dari hasil perhitungan biaya kemacetan kondisi saat ini dan prediksi biaya kemacetan pada saat ERP diberlakukan maka terdapat penghematan biaya akibat kemacetan sebesar Rp. Rp.532,291.998/jam untuk jam sibuk pagi. Sedangkan jam sibuk sore, penghematan biaya kemacetan sebesar Rp.294,167.785/jam. Sehingga sistem ERP ini berpotensi untuk diterapkan pada Jalan Medan Merdeka Barat karena menguntungkan bagi pengguna jalan disebabkan adanya penghematan biaya akibat kemacetan. Serta dengan adanya pengurangan volume kendaraan akan membuat derajat kejenuhan akan menjadi lebih baik jika dibandingkan pada kondisi saat ini.

\section{DAFTAR PUSTAKA}

[1] Susantono, Bambang. 2010. Electronic Road Pricing (ERP) Salah Satu Solusi Masalah 
Kemacetan di Kota Jakarta. Jakarta : Direktorat Jendral Tata RuangKementrian ATR/BPN.

[2] Sianipar, Arbie 2018. Analisis Potensi dan Kesiapan Penerapan Electronic Road Pricing di Wilayah Perkotaan. Warta Penelitian Perhubungan Vol.20 November 2018.

[3] Hajia M.C.,dkk. 2019. Penerapan Road Pricing Pada Ruas Jalan Arteri Primer Di Kota Manado (Studi Kasus: Jalan Sam Ratulangi Pertigaan Pikat). Jurnal Sipil Statistik Vol.7 No.1 Januari 2019. ISSN: 2337-6732.

[4] Fauzi, Muhammad Ridwan. 2017. Studi Kelayakan Penerapan Electronic Road Pricing Pada Jalan Embong Malang. Tugas Akhir Institut Teknologi Sepuluh Nopember.

[5] Saputra, Petrick Dwi dan Najid. 2018. Pengendalian Penggunaan Kendaraan Pribadi Dengan Strategi Parkir dan ERP Di SudirmanThamrin (DKI Jakarta). Jurnal Mitra Teknik Sipil Vol.1 No.2 November 2018. EISSN 2622-545X.

[6] Dinas Perhubungan Provinsi DKI Jakarat. 2012. Feasibility Study untuk ERP (Electronic Road Pricing). Jakarta.

[7] Direktorat Jendral Bina Marga. 2014. Pedoman Kapasitas Jalan Indonesia. Jakarta : Departemen Pekerjaan Umum.

[8] Hayati, Erna. 2014. Analisis Regresi Logistik Untuk Mengetahui Faktor - Faktor Yang Mempengaruhi
Frekuensi Kedatangan Pelanggan Di Pusat Perbelanjaan "X". Jurnal Universitas Islam Lamongan.

[9] Pd-T-15-2005-B. 2005. Perhitungan Biaya Operasi Kendaraan Bagian I : Biaya Tidak Tetap (Running Cost). Jakarta : Departemen Pekerjaan Umum.

[10] Susanti, Suci dan Maria Magdalena. 2015. Estimasi Biaya Kemacetan di Kota Medan. Jurnal Penelitian Transportasi Multimoda Vol.13 No.01 Maret 2015.

[11] Basuki, Imam dan Siswadi. 2008. Biaya Kemacetan Ruas Jalan Kota Yogyakarta. Jurnal Teknik Sipil Vol.9 No.1 Oktober 2008. 
Nama Penulis, Judul 3 kata saja.....

\section{Biaya Kemacetan}

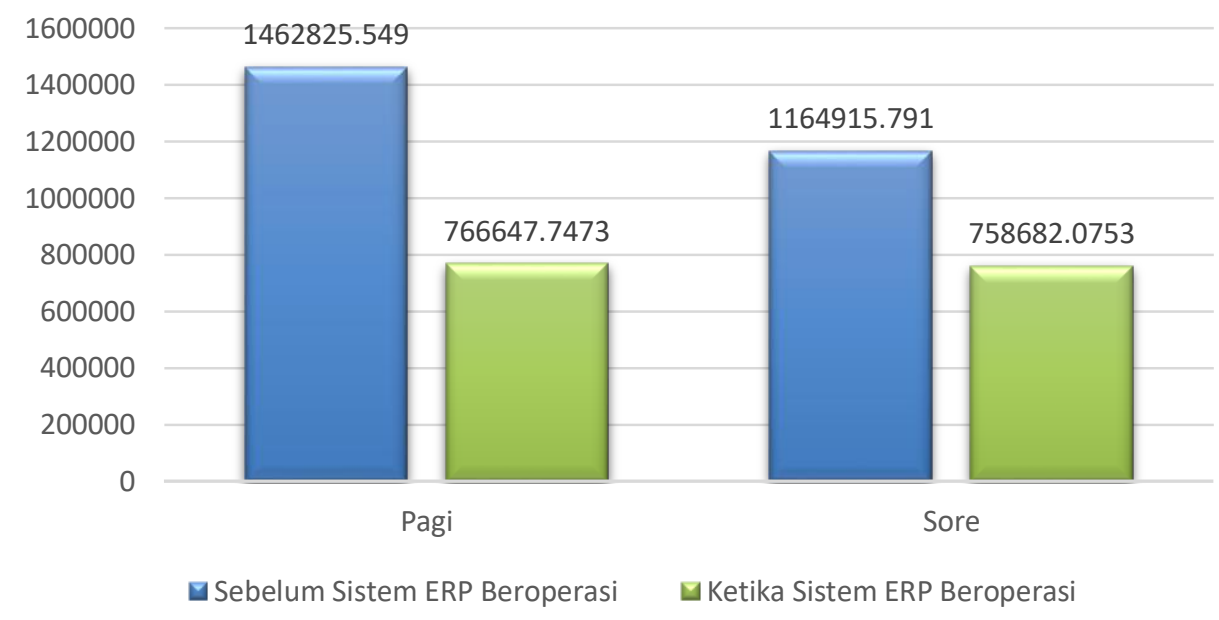

Gambar 2. Grafik Biaya Kemacetan Jalan Medan Merdeka Barat dan Prediksi Biaya Kemacetan pada saat ERP beroperasi 